\title{
EFEKTIVITAS STRATEGI PEMBELAJARAN PEER TUTORING DALAM MENINGKATKAN SELF-REGULATED LEARNING (SRL) PADA MATA PELAJARAN PLATFORM KOMPUTASI AWAN KELAS XI SISTEM INFORMASI JARINGAN DAN APLIKASI SMK NEGERI 26 JAKARTA
}

\author{
Nuraini Azizah", Yuliatri Sastrawijaya ${ }^{2}$, M. Duskarnaen ${ }^{3}$ \\ ${ }^{1}$ Mahasiswa Prodi Pendidikan Teknik Informatika dan Komputer, Teknik Elektro, FT - UNJ \\ ${ }^{2,3}$ Dosen Prodi Pendidikan Teknik Informatika dan Komputer, Teknik Elektro, FT - UNJ \\ =nuraini.azizah@gmail.com, ${ }^{1}$ yuliatri@unj.ac.id, ${ }^{3}$ duskarnaen@unj.ac.id
}

\begin{abstract}
Abstrak
Penelitian ini bertujuan untuk mengetahui efektivitas peningkatan self-regulated learning siswa kelas XI Sistem Informasi Jaringan dan Aplikasi SMK Negeri 26 Jakarta setelah diberikan treatment strategi pembelajaran peer tutoring pada mata pelajaran platform komputasi awan. Penelitian ini dilakukan di SMK Negeri 26 Jakarta, dilaksanakan pada bulan April - Mei 2019. Metode penelitian yang digunakan adalah quasy eskperimental yang diberikan perlakuan berupa strategi pembelajaran peer tutoring pada kelas ekperimen yang dibuat perkelompok dengan masing-masing kelompok terdiri dari satu tutor dan pada kelas kontrol diberikan perlakuan pembelajaran biasa tanpa dibuat kelompok. Kelas XI SIJA 1 yang merupakan kelas ekperimen terdiri dari 33 siswa dan kelas XI SIJA 2 yang merupakan kelas kontrol terdiri dari 36 siswa. Untuk mendapatkan data penelitian ini, dilaksanakan pretest sebelum diberikan treatment dan posttest setelah diberikan treatment. Berdasarkan hasil penelitian didapatkan siswa kelas eksperimen yang diberikan treatment peer tutoring mendapatkan rata-rata skor 125,512 sedangkan untuk kelas kontrol mendapatkan rata-rata skor 114,06. Dengan demikian HO ditolak, sehingga dapat disimpulkan bahwa strategi pembelajaran peer tutoring efektif dalam meningkatkan self-regulated learning siswa.
\end{abstract}

Kata Kunci : Peer Tutoring, Self-Regulated Learning, Platform Komputasi Awan

\section{Pendahuluan}

Undang-Undang Nomor 20 tahun 2003 tentang Sistem Pendidikan Nasional menjelaskan bahwa pendidikan adalah usaha sadar dan terencana untuk mewujudkan suasana belajar dan proses pembelajaran agar peserta didik secara aktif mengembangkan potensi dirinya untuk memiliki kekuatan spiritual keagamaan, pengendalian diri, kepribadian, kecerdasan, akhlak mulia serta keterampilan yang diperlukan dirinya, masyarakat, bangsa dan negara.

Pendidikan yang mampu mendukung pembangunan bangsa di masa mendatang adalah yang mampu mengembangkan potensi peserta didik sehingga yang bersangkutan mampu menghadapi dan memecahkan problema kehidupan yang dihadapinya (Trianto, 2009:1). Hal tersebut bisa tercapai apabila unsur-unsur pendidikan saling mendukung untuk menciptakan suasana belajar yang kondusif. Salah satu unsur yang sangat vital yaitu guru. Guru merupakan kunci keberhasilan dalam mendidik siswa agar disiapkan menjadi generasi penerus bangsa yang memiliki integritas, berwawasan luas serta berakhlak mulia. Untuk itu dibutuhkan guru yang mumpuni dan kompeten di bidangnya.

Selain guru, unsur yang tidak kalah pentingnya adalah strategi pembelajaran yang diterapkan. Menurut Colin Marsh (2005:66-67) diacu dalam Nindya Rahmah Septiani (2017). Strategi pembelajaran adalah suatu cara untuk meningkatkan pembelajaran yang optimal bagi siswa termasuk bagaimana mengelola disiplin kelas dan organisasi pembelajaran. Menurut Colin Marsh mengutip Duck, diacu dalam Haryanto \& Suyono (2016:21) menyatakan bahwa ada dua strategi pembelajaran yang pokok, yaitu pembelajaran berpusat pada guru (teachercentered) dan pembelajaran berpusat pada siswa (student-centered). Jika strategi yang diterapkan tepat maka tujuan belajar tercapai sesuai dengan yang diharapkan.

Kurikulum 2013 mengupayakan pembelajaran berpusat pada siswa (student centered). Pembelajaran diharapkan mampu menstimulus siswa untuk terlibat aktif dalam proses belajar. Sehingga belajar menjadi bermakna dan akhirnya siswa mampu 
memutuskan apa yang akan dipelajari dan bagaimana cara mempelajarinya. Tanpa ada keinginan siswa untuk aktif terlibat dalam belajar, maka keberhasilan belajar tidak akan tercapai.

Kemandirian belajar akan membantu siswa dalam menentukan tujuan yang spesifik, menggunakan lebih banyak strategi belajar, memonitor sendiri proses belajar, dan lebih sistematis dalam mengevaluasi kemajuan siswa itu sendiri (Santrock, 2010: 296, diacu dalam Putri Yulianti, 2016). Dengan demikian dalam proses belajar, kemandirian belajar siswa sangat diperlukan, seperti mengatur jam belajar sendiri, memilih kegiatan-kegiatan mana yang dapat menunjang prestasi akademiknya, menyusun strategi-strategi dalam belajar dan perilakuperilaku lainnya yang menandakan bahwa siswa bertanggung jawab dan dapat berprestasi di sekolah.

Ketika peneliti melaksanakan Praktik Kegiatan Mengajar di SMKN 26 Jakarta dari bulan Agustus hingga Desember 2018 peneliti melakukan observasi di kelas yang diajar yaitu XI SIJA (Sistem Informasi Jaringan dan Aplikasi). Kelas ini merupakan angkatan pertama yang sebelumnya adalah jurusan Teknik Komputer Jaringan. Jurusan ini terdiri dari 4 tingkatan kelas yaitu X SIJA, XI SIJA, XII TKJ, dan XIII TKJ. Masing masing tingkat terdiri dari dua kelas dan berisi 32 - 36 siswa.

Sistem Informasi Jaringan dan Aplikasi merupakan kompetensi keahlian baru di program keahlian teknik komputer dan informatika. SIJA sebutan dari Sistem Informatika Jaringan dan Aplikasi dibuka pada tahun pelajaran 2017/2018. Pembukaan jurusan/kompetensi keahlian ini ditandai dengan terbitnya surat keputusan Direktorat Jendral Pendidikan Dasar dan Menengah tentang spektrum keahlian Pendidikan menengah kejuruan NO.4678/D/KEP/2016. Membekali siswa pengetahuan, keterampilan, dan sikap agar kompeten terkait kemampuan algoritma, dan pemrograman komputer, perakitan komputer, perakitan jaringan komputer, dan pengoperasian perangkat lunak, dan internet.

Adapun mata pelajaran Sistem Komputer, Komputer dan Jaringan Dasar, Pemrograman Dasar. Dasar Desain Grafis, Dasar Program Keahlian, Infrastruktur Komputasi Awan (IaaS), Layanan Komputasi Awan (SaaS), Sistem Internet of Things (SloT), Produk Kreatif dan Kewirausahaan, dan Platform Komputasi Awan (PaaS). Platform Komputasi Awan merupakan salah satu mata pelajaran wajib di jurusan SIJA yang mempelajari tentang konsep sistem jaringan dan melakukan berbagai prosedur konfigurasi pada sistem operasi berbasis virtual yang menjadikan internet sebagai pusat pengelolaan data dan aplikasi.

Beberapa fakta yang ditemukan selama praktik mengajar di antaranya sering tertinggalnya siswa ketika guru mempraktikan tutorial konfigurasi, akibatnya ada yang merasa jenuh, tidak fokus belajar, bermain game, dan mengobrol dengan temannya. Selain itu terdapat beberapa siswa tidak tepat waktu dalam mengumpulkan tugas. Ketika guru berhalangan mengajar beberapa siswa terlihat menonton tayangan Youtube yang tidak berkaitan dengan materi sekolah dibanding mencari informasi terkait materi materi belajar.

Pada tanggal 8 Maret 2019 observasi dilakukan dengan mewawancarai Ibu Dwi Puspitaningtyas, S.Pd sebagai wali kelas XI SIJA SMKN 26. Hasil wawancara menunjukan bahwa 10-15 siswa dari 36 siswa (36\%) menonton Youtube dan bermain game saat pelajaran. Hal ini dilakukan diam-diam. Sekitar 10-13 siswa dari 36 siswa $(32 \%)$ sering terlambat mengumpulkan tugas yang dikumpulkan secara online. Bahkan saat guru tidak mengingatkan batas terakhir pengumpulan tugas presentase mencapai angka $56 \%$ yaitu 20 siswa dari 36 siswa Masalah lainnya adalah ketika guru banyak mengajar dengan metode ceramah barisan yang duduk di belakang tidak fokus sehingga mereka tidak mendengarkan apa yang guru sampaikan.

Hal ini menunjukan bahwa SRL (SelfRegulated Learning) masih kurang. Maka dibutuhkan suatu strategi pembelajaran yang mendukung untuk meningkatkan kemandirian belajar, interaksi, dan partisipasi siswa di kelas sehingga tujuan pembelajaran tercapai sesuai yang diharapkan. Di sisi lain ditemukan beberapa siswa sudah memiliki kemandirian belajar yang baik. Mampu mengontrol apa yang mereka butuhkan untuk mencari pengetahuan ataupun melatih kemampuan yang menunjang akademik dengan mengikuti kegiatan IT Club. Sehingga kondisi ini merupakan kesempatan untuk mempengaruhi beberapa siswa lainnya dengan tingkat SLR rendah.

Kendala lain ditemukan pada mata pelajaran ini adalah belum mempunyai silabus. Siswa yang belajar mandiri dengan strategi pembelajaran peer tutoring akan distimulus oleh guru untuk mencari bahan belajar yang topiknya sudah ditentukan oleh guru berdasarkan KI dan KD. Maka siswa belajar secara mandiri untuk menggali pengetahuan dari dalam dirinya dan mencari sebanyak-banyaknya informasi untuk menghadapi kesulitan-kesulitan bersama teman sekelompoknya dengan bimbingan dari guru.

Maka berdasarkan hasil observasi, salah satu langkah untuk mengatasi masalah tersebut adalah dengan menerapkan strategi pembelajaran peer putoring. Sehingga peneliti tertarik untuk melakukan penelitian dengan judul "Efektivitas Strategi Pembelajaran Peer Tutoring Dalam Meningkatkan Self-Regulated Learning (SRL) Pada Mata Pelajaran Platform Komputasi Awan 
Kelas XI Sistem Informasi Jaringan Dan Aplikasi SMK Negeri 26 Jakarta.

\section{Landasan Teori}

\subsection{Definisi Self-Regulated Learning}

Menurut Zimmerman (1990) selfregulated learning adalah tingkatan di mana siswa secara aktif melibatkan metakognisi, motivasi, dan perilaku dalam proses belajar. Selfregulated learning juga didefinisikan sebagai bentuk belajar individual dengan bergantung pada motivasi belajar mereka, secara otonomi mengembangkan dan pengukuran (kognisi, metakognisi, dan perilaku), dan memonitor kemajuan belajarnya (Baumert et al., 2002, diacu dalam Pri Ariadi Cahya Dinata, dkk, 2016).

Menurut Wolters, dkk (2003:2), diacu dalam Ryndi Mardoh (2015), SRL merupakan proses konstruktif aktif di mana siswa menetapkan tujuan belajarnya dan kemudian berusaha untuk memonitor, mengatur, dan mengontrol kognisi, motivasi, dan tingkah lakunya agar sesuai dengan tujuannya dan kondisi kontekstual dari lingkungannya. Sedangkan menurut Santrock (2007: 149), diacu dalam Ryndi Mardoh (2015), SRL adalah self-generation dan self-monitoring terhadap berbagai pikiran, perasaan, dan perilakunya agar dapat meraih tujuan.

\subsection{Strategi Self-Regulated Learning}

Menurut Zimmerman (1989) mengembangkan langkah - langkah dalam mencapai regulasi diri sebagai berikut :

a. Observasi Diri (memonitor diri sendiri),

ketika observasi dilakukan akan menghasilkan persepsi tentang kemajuan, hal itu dapat memotivasi seseorang untuk meningkatkan kinerjanya dengan mengubah apa yang telah dilakukannya. Sebelum individu mengubah tingkah lakunya, ia harus terlebih dahulu menyadari tingkah lakunya. Hal ini melibatkan kegiatan memantau atau memonitor tingkah laku dirinya. Semakin sistematis individu memantau tingkah lakunya, maka semakin cepat individu sadar akan apa yang dilakukannya.

b. Evaluasi Diri (menilai diri sendiri), pada tahap ini siswa menentukan apakah tindakan yang dilakukan sesuai dengan yang diinginkan, yaitu sesuai dengan standar pribadi individu tersebut. Standar pribadi berasal dari informasi yang diperoleh individu dari orang lain. Siswa membandingkan kinerja seseorang dengan suatu standar akan memberikan informasi tentang kemajuan yang telah dicapai. Dengan melakukan penilaian diri, siswa dapat menentukan apakah tindakannya berada pada jalur yang benar.

c. Reaksi Diri (mempertahankan motivasi internal), pada tahap ini siswa menciptakan dorongan untuk perilaku diri sendiri, mengakui dan membuktikan kompetensi yang dimiliki, kemudian merasa puas dengan diri sendiri sehingga dapat meningkatkan minat dalam mengerjakan sesuatu.

Sementara menurut North Central Regional Educational Laboratory (NCRL), diacu dalam Pri Ariadi Cahya Dinata, dkk, (2016), terdapat tiga strategi metacognitive selfregulation yang dapat dikembangkan untuk meraih kesuksesan belajar siswa, yaitu:

a. Tahap merencanakan belajar, meliputi proses memperkirakan waktu yang dibutuhkan untuk menyelesaikan tugas belajar, merencanakan waktu belajar dalam bentuk jadwal serta menentukan skala prioritas dalam belajar, mengorganisasikan materi pelajaran, mengambil langkah-langkah yang sesuai untuk belajar dengan menggunakan berbagai strategi belajar (outlining, mind mapping, speed reading, dan strategi belajar lainnya).

b. Tahap proses sadar belajar, meliputi proses untuk menetapkan tujuan belajar, mempertimbangkan sumber belajar yang akan dan dapat diakses (contoh: menggunakan buku teks, mencari buku sumber di perpustakaan, mengakses internet di lab. komputer, atau belajar di tempat sunyi), menentukan bagaimana kinerja terbaik siswa akan dievaluasi, mempertimbangkan tingkat motivasi belajar, menentukan tingkat kesulitan belajar siswa.

c. Tahap monitoring dan refleksi belajar, meliputi proses merefleksikan proses belajar, memantau proses belajar melalui pertanyaan dan tes diri (self-testing, seperti mengajukan pertanyaan, apakah materi ini bermakna dan bermanfaat bagi saya? bagaimana pengetahuan pada materi ini dapat saya kuasai? mengapa saya mudah/sukar menguasai materi ini?, menjaga konsentrasi dan motivasi tinggi dalam belajar. 
Siswa-siswa yang belajar dengan regulasi diri dapat diistilahkan sebagai siswa 'ahli'. Siswa ahli mengenal dirinya sendiri dan bagaimana mereka belajar dengan sebaik-baiknya. Mereka mengetahui gaya pembelajaran yang disukainya, apa yang mudah dan sulit bagi dirinya, bagaimana cara mengatasi bagian-bagian sulit, apa minat dan bakatnya, dan bagaimana cara memanfaatkan kekuatan/kelebihannya (Woolfolk, 2008, Pri Ariadi Cahya Dinata, Rahzianta, Muhammad Zainuddin, 2016). Mereka juga tahu materi yang sedang dipelajarinya; semakin banyak materi yang mereka pelajari semakin banyak pula yang mereka ketahui, serta semakin mudah untuk belajar lebih banyak (Alexander, 2006, Pri Ariadi Cahya Dinata, Rahzianta, Muhammad Zainuddin, 2016). Mereka mungkin mengerti bahwa tugas belajar yang berbeda memerlukan pendekatan yang berbeda pula. Merekapun menyadari bahwa belajar seringkali terasa sulit dan pengetahuan jarang yang bersifat mutlak; biasanya ada banyak cara yang berbeda untuk melihat masalah dan ada banyak macam solusi (Pressley, 1995; Winne, 1995, diacu dalam Pri Ariadi Cahya Dinata, dkk, 2016).

\subsection{Aspek-aspek Self-Regulated Learning}

Menurut Zimmerman (1990) menyatakan bahwa keterlibatan akademik siswa dalam proses pembelajaran seharusnya meliputi aspek kognitif, afektif, dan psikomotorik. Pendapat di atas diperjelas oleh Muhammad Nur Wangid (2013: 260) diacu dalam Ryndi Mardoh (2015), sebagai berikut:

a. Kemampuan mengatur diri aspek kognitif (cognitive self-regulation) adalah sejauh mana individu dapat merefleksikan diri dan dapat merencanakan dan berpikir kedepan. Misalnya pada fase perencanaan siswa akan memikirkan keterlaksanaannya kegiatan belajar, kemudian pada fase pelaksanaan siswa akan menerapkan bagaimana strategi kognitif yang telah dibuatnya, dan pada fase refleksi diri siswa akan memahami keberhasilan dan kegagalan dari tugas belajarnya. Secara singkat aspek ini dapat diartikan sebagai persepsi individu tentang pengetahuan siswa mengenai keadaan dan proses pemikiran mereka sendiri.

b. Kemampuan diri aspek sosial-emosional (social-emosional self-regulation) atau afektif adalah kemampuan menghambat tanggapan negatif dan menunda gratifikasi. Maksudnya adalah kemampuan individu untuk mengendalikan respon-respon emosional negatif ketika mendapatkan suatu kondisi atau stimulus negatif, dan kemampuan untuk menahan memuaskan suatu keinginan demi tujuan yang mulia. Misalnya pada fase perencanaan siswa akan terdorong dan termotivasi dalam pelaksanaan tugas belajar, kemudian pada fase pelaksanaan aspek ini berfungsi untuk memonitor dan mengontrol emosi dan motivasinya, kemudian siswa mengekspresikannya dengan reaksi. Reaksi afektif seperti rasa puas jika memperoleh keberhasilan dan rasa kecewa jika mengalami kegagalan.

c. Kemampuan mengatur diri aspek perilaku merupakan kemampuan individu dalam memilih tingkah lakunya yang sesuai dengan konteks dan prioritas kebutuhan yang diperlakukan. Pada aspek perilaku ini dapat dilihat dengan bagaimana siswa dapat memahami dan mengerti apa yang mereka pelajari. Misalnya pada fase perencanaan siswa akan mempersiapkan pelaksanaan tugasnya, kemudian melaksanakan tugas sesuai dengan strategi yang telah dibuat dilanjutkan dengan evaluasi dan perbaikan dari tugas belajarnya.

Dari pendapat ahli di atas aspek-aspek yang berkaitan dengan self-regulated learning meliputi aspek kemampuan mengatur diri (kognitif), aspek kemampuan sosial-emosional (afektif), dan aspek kemampuan dalam perilaku (psikomotorik). Self-regulated learning menuntut siswa untuk bertanggung jawab terhadap proses belajarnya mencangkup ketiga aspek tersebut yang meliputi aspek kognitif, afektif, dan psikomotorik yang akan dijadikan skala pengukuran dalam penelitian untuk mengungkap kemampuan self-regulated learning pada siswa kelas XI SIJA di SMK Negeri 26 Jakarta.

\subsection{Faktor Pendukung Self-Regulated Learning}

Menurut Bandura diacu dalam Schunk (2009:79) perilaku manusia dibahas dalam kerangka determinisme timbal balik antara perilaku, lingkungan dan pribadi seperti berikut:

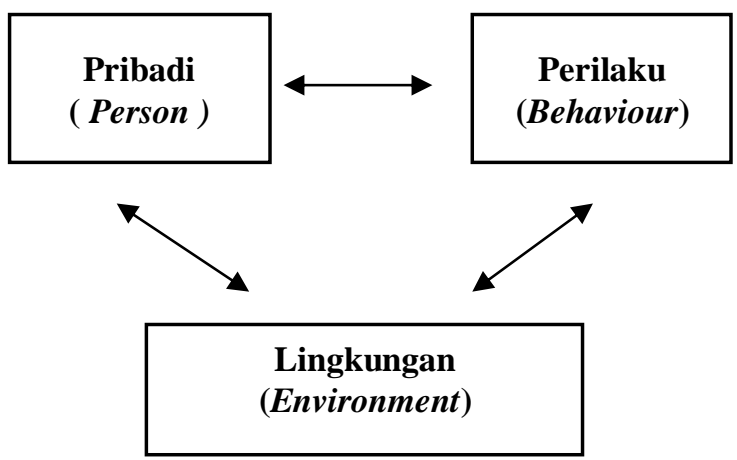

Gambar 2.1. Model Interaksi Timbal Balik (Bandura dalam Schunk, 2009:79) 
Dari Gambar 2.1 dapat dijelaskan bahwa menurut teori sosial kognitif terdapat tiga hal yang mempengaruhi seseorang sehingga melakukan SRL:

Faktor pribadi (person) pada triadic dijelaskan bahwa siswa dapat menggunakan proses pribadi untuk mengatur strategi perilaku dan lingkungan belajar. Pribadi (person) tingkah laku (behavior), dijelaskan bahwa pada pribadi seorang terdapat suatu keyakinan tentang kemampuan untuk mengatur dan menyelesaikan suatu tugas yang diperlukan untuk mencapai hasil tertentu dalam berbagai bentuk dan tingkat kesulitan (self-eficcacy). Individu yang memiliki self-eficcacy tinggi akan melakukan usaha untuk mencapai tujuan. Misalnya: harapan-harapan dan nilai-nilai pribadi mempengaruhi tingkah laku. Dengan demikian individu tersebut akan memiliki self-regulated learning (SRL). Individu yang memiliki SRL mempunyai kemampuan untuk mengatur proses belajar yang meliputi perencanaan, pelaksanaan, dan evaluasi belajar, baik dalam aspek kognitif, afektif dan psikomotor untuk tujuan belajar. Sedangkan pada faktor perilaku (behavior) - pribadi (person), terjadi jika SRL pada individu mencapai tujuan yang diharapkan, maka individu tersebut akan terus melakukan atau meningkatkan perilaku SRL sehingga menjadi perilaku yang melekat pada diri (behavior).

Faktor pribadi (person) - lingkungan (environment), dijelaskan pada siswa yang mengalami kesulitan belajar akan terjadi interaksi antara pribadi dengan faktor lingkungan. Siswa yang memiliki kesulitan belajar akan mengalami rendah diri, di dalam lingkungan sosial akan bergabung dengan siswa yang sama-sama memiliki kesulitan belajar. Hal tersebut tidak akan terjadi jika individu memiliki self eficcacy, individu yang memiliki self eficcacy akan percaya diri, sehingga individu tersebut dapat mengatur lingkungan, seperti: berinteraksi sosial dengan teman, orang tua, dan guru serta masyarakat luas. Faktor lingkungan (environment) - pribadi (person), pada siswa yang mengalami kesulitan belajar dapat diberikan umpan balik (feedback) dari lingkungan, seperti guru memberikan motivasi kepada siswa "Aku yakin kamu bisa melakukannya". Dengan memberikan motivasi tersebut, maka keyakinan dan rasa percaya diri pada siswa semakin meningkat.

Faktor perilaku siswa dan lingkungan kelas saling mempengaruhi satu sama lain. Contohnya: guru memberikan perintah dan meminta siswa untuk mengarahkan perhatiannya ke depan papan tulis. Pengaruh lingkungan pada perilaku terjadi ketika siswa melihat papan tanpa banyak pertimbangan (lingkungan-perilaku). Sedangkan faktor perilaku (behavior) lingkungan (environment), dijelaskan melalui perilaku siswa yang sering mengubah lingkungan pembelajaran. Jika guru mengajukan pertanyaan pertanyaan dan siswa memberikan jawaban yang salah, guru dapat melakukan pembelajaran ulang beberapa poin daripada melanjutkan pelajaran (perilaku-lingkungan). Agar metode pembelajaran yang dilakukan oleh guru tidak membosankan, guru bisa melakukan metode metode pembelajaran yang lebih variatif.

Pemaparan diatas menunjukan bahwa selama proses SRL berlangsung ada 3 (tiga) faktor yang berpengaruh dan saling berkaitan antara faktor pribadi, tingkah laku, dan lingkungan dalam kemampuan self-regulated learning siswa. Kemudian ada banyak faktor untuk pembelajaran efektif guna mendorong self regulation di kelas. Menurut Zumbrunn, Tadlock \& Roberts (2011 : 14 - 16) diacu dalam Catur Gesti Anggraini (2014) ada 4 faktor untuk pembelajaran efektif yaitu :

a. Instruksi Langsung dan Permodelan (Direct Instruction and Modeling) Instruksi langsung ini menjelaskan strategi pembelajaran yang berbeda-beda yang akan digunakan serta ketrampilan apa saja yang terlibat dari strategi tersebut. Untuk lebih mudah memahaminya digunakan teknik permodelan agar siswa lebih memahami. Saat guru menjelaskan proses berfikir seorang siswa dan apa saja yang seharusnya dilakukan untuk menyelesaikan tugasnya, dengan ini siswa akan lebih paham apa yang seharusnya ia lakukan.

b. Praktik yang dibimbing dan Mandiri (Guided and Independent Practice) Praktik yang dibimbing dapat meningkatkan self-regulated learning siswa dan juga memotivasinya. Selama praktik tanggung jawab belajar bergeser dari guru ke peserta didik, contohnya dalam praktik belajar menulis guru memperhatikan peserta didiknya guru menawarkan bantuan terhadap peserta didik apabila mengalami kesulitan dan bila diperlukan saja. Secara alami kemandirian peserta didik akan muncul selama praktik dibimbing ini berlangsung.

c. Dukungan Sosial dan Umpan Balik (Social Support and Feedback) Dukungan sosial dari guru dan teman sebaya berperan penting untuk siswa karena akan menjadikan siswa lebih mandiri. Seringkali dukungan sosial timbul dari umpan balik yang diberikan dari guru maupun teman sebayanya. Umpan balik yang efektif adalah umpan balik yang berisikan informasi yang mencakup apakan siswa sudah melakukan tugasnya 
dengan baik, apa yang mereka butuhkan untuk memperbaikinya, dan langkah langkah apa saja yang dapat meningkatkan pekerjaan mereka.

d. Praktik Reflektif (Reflective Practice) Praktik ini memungkinkan guru untuk menyelidiki kemungkinan alasan dan menjelaskan efektivitas strategi pembelajaran yang diberikan di dalam kelas. Melalui refleksi bijaksana, eksperimen, dan evaluasi, guru dapat menciptakan pengalaman belajar yang bermakna bagi siswa mereka.

Berdasarkan uraian di atas dapat disimpulkan bahwa faktor pendukung siswa untuk menjadi seorang self-regulated learner itu ada 4 yaitu: Instruksi Langsung dan Permodelan (Direct Instruction and Modeling), Praktik yang dibimbing dan Mandiri (Guided and Independent Practice), Dukungan Sosial dan Umpan Balik (Social Support and Feedback), Praktik Reflektif (Reflective Practice).

\subsection{Meningkatkan Self-Regulated Learning}

Dalam meningkatkan self-regulated learning (Zimmerman, 1990 : 11, diacu dalam Catur Gesti Anggraini, 2014) menyebutkan bahwa seorang siswa harus mempunyai motivasi diri yang tinggi dan mampu memotivasi diri sendiri. McCombs dan Marzano (Zimmerman, 1990 : 11, diacu dalam Catur Gesti Anggraini, 2014) menyimpulkan bahwa persepsi siswa terhadap tugas akademiknya disaring melalui sistem struktur diri, keyakinan diri, tujuan diri dan evaluasi diri. Ketika seorang siswa sudah memahami akan tugasnya sebagai seorang pelajar, mereka juga akan sadar dan mampu mengembangkan diri mereka sendiri serta mampu menentukan tujuan mereka dan mampu memotivasi diri mereka sendiri.

Berdasarkan penelitian yang dilakukan Ryndi Mardoh (2015) menyimpulkan bahwa metode peer tutoring efektif meningkatkan selfregulated learning siswa Sekolah Menengah Kejuruan. Ryndi Mardoh menjelaskan bahwa dalam pembelajaran dengan tutor sebaya, seorang tutor diharapkan menggunakan kemampuannya untuk memberikan pengajaran dan mengarahkan siswa untuk mencapai solusi dan pemahaman sesuai dengan target pembelajaran yang telah ditetapkan.

Selain itu, dalam proses strategi peer tutoring (tutor sebaya) ini terjadi proses membangun dan memberitahukan pengetahuan. Ketika tutor memberikan penjelasan pada anggota kelompoknya, tutor melakukan penjelasan konsep dan prinsip serta memunculkan ide baru. Selain itu, ketika anggota kelompok mengajukan pertanyaan yang spesifik dan mendalam, hal itu akan mendukung anggota kelompok dalam merefleksikan pengembangan pengetahuannya, di mana tutor berperan membantu proses ini sekaligus juga menguatkan pemahamannya. Karena, tutor dalam tutor teman sebaya akan memberikan dampak positif terhadap siswa karena dapat memberikan motivasi terhadap siswa untuk bisa menjadi lebih baik, setidaknya meniru seperti tutornya. Hal ini lah yang akan berpengaruh terhadap peningkatan self-regulated learning siswa.

\subsection{Platform Komputasi Awan}

Platform komputasi awan adalah salah satu mata pelajaran wajib di jurusan Sistem Informasi Jaringan dan Aplikasi. Berdasarkan struktur kurikulum mata pelajaran platform komputasi awan disampaikan di kelas XI dan XII semester 1 dan 2 masing masing 5 jam pelajaran. Untuk Kelas XI semester 1 mempelajari konsep sistem operasi jaringan, menerapkan prosedur konfigurasi DNS Server, Web Server, Mail Server, NTP (Network Time Protocol) dan FTP (File Transfer Protocol), mampu menganalisa dan memecahkan masalah konfigurasi. Sedangkan untuk Kelas XI semester 2 menekankan kepada konsep virtualisasi, menerapkan prosedur konfigurasi virtualisasi, menganalisa dan memecahkan masalah konfigurasi.

Berdasarkan peta kedudukan bahan ajar, mata pelajaran platform komputasi awan memiliki keterkaitan dengan mata pelajaran infrastruktur komputasi awan dan layanan komputasi awan. Pada mata pelajaran platform komputasi awan mempelajari tentang konsep sistem jaringan dan menyediakan tempat untuk melakukan berbagai konfigurasi pada sistem operasi berbasis virtual yang menjadikan internet sebagai pusat pengelolaan data dan aplikasi. Pada mata pelajaran layanan komputasi awan mempelajari bagaimana menyediakan layanan yang memudahkan mengakses software (aplikasi) dengan mudah tanpa perlu menyediakan storage khusus pada perangkat untuk menyimpan aplikasi tersebut. Sedangkan untuk infrastruktur layanan komputer mempelajari bagaimana memberikan kemudahan jika komputer virtual menampung data lebih dari kapasitas yang tersedia misalnua dengan menambahkan RAM atau storage dengan cepat.

SMK Negeri 26 Jakarta memiliki bidang keahlian Sistem Informasi Jaringan dan Aplikasi dengan program belajar 4 tahun. Di mana para lulusan diharapkan mampu bersaing di dunia kerja khususnya di bidang Sistem Informasi Jaringan dan Aplikasi. Peneliti melakukan penelitian di kelas XI SIJA semester 2 Tahun Pelajaran 2018/2019. Beberapa materi Platform Komputasi Awan berdasarkan silabus untuk semester 2 berisi pemahaman konsep virtualisasi, menerapkan 
prosedur, menganalisis dan mengevaluasi konfigurasi virtualisasi pada sistem operasi.

\subsection{Definisi Peer Tutoring}

Menurut Febianti (2014) tutor sebaya (peer tutoring) adalah sebuah strategi pembelajaran yang sedang menjadi tren sekarang. Peer tutoring memang menjadi metode yang menjadikan siswa tidak bosan, sementara guru juga tidak suntuk. Peer tutoring dalam bahasa Indonesia lebih dikenal dengan istilah tutor sebaya. Dejnozken dan Kopel dalam American Education Encyclopedia menyebutkan pengertian tutor sebaya adalah sebagai berikut:"Tutor sebaya adalah sebuah prosedur siswa mengajar siswa lainnya. Tipe pertama adalah pengajar dan pembelajar dari usia yang sama. Tipe kedua adalah pengajar yang lebih tua usianya dari pembelajar. Tipe yang lain kadang dimunculkan pertukaran usia pengajar".

Ketika mereka belajar dengan tutor sebaya, peserta didik juga mengembangkan kemampuan yang lebih baik untuk mendengarkan, berkonsentrasi, dan memahami apa yang dipelajari dengan cara yang bermakna. Penjelasan melalui tutor sebaya kepada temannya lebih memungkinkan berhasil dibandingkan guru. Peserta didik melihat masalah dengan cara yang berbeda dibandingkan orang dewasa dan mereka menggunakan bahasa yang lebih akrab.

Menurut Wihardit (1995; dalam Djalil 1997) diacu dalam Chilmiyyatul Musyrifah (2016) mengatakan bahwa pengertian tutor sebaya adalah seorang siswa pandai yang membantu belajar siswa lainnya dalam tingkat kelas yang sama. Sedangkan menurut Miller (1989), diacu Chilmiyyatul Musyrifah (2016) berpendapat bahwa "Setiap saat murid memerlukan bantuan dari murid lainnya, dan murid dapat belajar dari murid lainnya". Dari beberapa pendapat diatas, dapat disimpulkan bahwa tutor sebaya (peer tutoring) adalah strategi pembelajaran dengan pendekatan kooperatif di mana peserta didik ada yang berperan sebagai pengajar (biasanya siswa yang lebih pandai dari siswa yang lain) dan peserta didik yang lain berperan sebagai pembelajar, baik pada usia yang sama atau pengajar berusia lebih tua dari pembelajar, untuk membantu belajar dalam tingkat kelas yang sama, untuk mengembangkan kemampuan yang lebih baik untuk mendengarkan, berkonsentrasi, dan memahami apa yang dipelajari dengan cara yang bermakna, karena penjelasan yang diberikan menggunakan bahasa yang lebih akrab.

\subsection{Manfaar Peer Tutoring}

Peer tutoring (tutor sebaya) membantu siswa lain baik secara personal atau dalam kelompok kecil melanjutkan diskusi kelas, mengembangkan keterampilan belajar, mengevaluasi pekerjaan, menyelesaikan masalah tertentu dan mendorong pembelajaran mandiri (Colvin 2007; Falchikov 2001; Goodlad 1998; Goodlad 1998; Boud et al 2001, diacu dalam Karen Arrand, 2014)

Berdasarkan penelitian yang dilakukan oleh Karen Arrand dari Coventry University, peer tutoring ternyata cukup signifikan dalam meningkatkan kepercayaan diri dan meningkatkan kemampuan menjelaskan (artikulasi). Para siswa dengan skor kepercayaan lebih rendah pada awalnya semua mencetak persentase perubahan yang lebih tinggi setelah melakukan kegiatan belajar peer tutoring. Semua siswa mencatat peningkatan kepercayaan diri dalam keterampilan presentasi (termasuk artikulasi dan penjelasan).

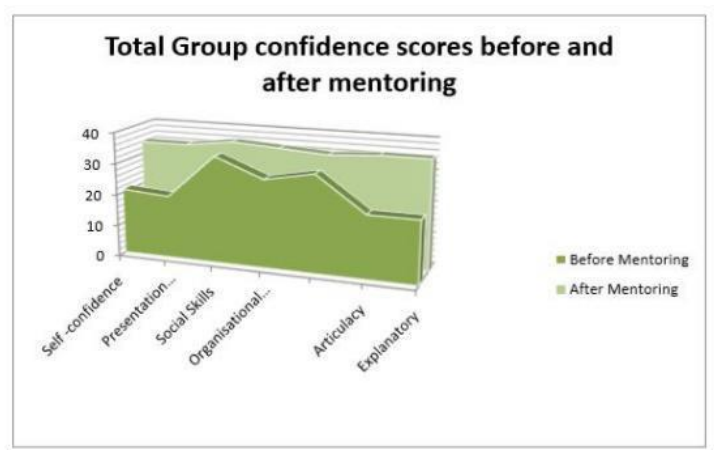

\section{Gambar 2.2. Hasil Penelitian Karen Arrand dari Coventry University}

Dari Gambar 2.2. menunjukan hasil penelitian sebelum dan sesudah dilakukan peer tutoring. Kepercayaan diri dan kemampuan menjelaskan (artikulasi) terlihat yang paling tinggi mengalami peningkatannya.

Penelitian lainnya yang dilakukan Greenwood (I Wayan, 2012) manfaat dari tutor teman sebaya yaitu mengembangkan perilaku sosial dan disiplin siswa. Dalam penelitiannya Greenwood menemukan adanya peningkatan kepercayaan diri dan kemampuan diri melalui tutor teman sebaya. Selain Greenwood, Alwi (Ruseno Arjanggi \& Titin Suprihatin, 2010) dalam penelitiannya menyebutkan bahwa ada pengaruh yang signifikan dari metode tutor teman sebaya terhadap motivasi belajar siswa.

Berdasarkan penjelasan beberapa ahli di atas dapat disimpulkan bahwa manfaat dari peer 
tutoring adalah mengembangkan keterampilan belajar, mengevaluasi pekerjaan, menyelesaikan masalah tertentu, mengembangkan perilaku sosial dan disiplin siswa serta dapat meningkatkan motivasi siswa dalam belajar sehingga mendorong pembelajaran mandiri. Semua manfaat dari tutor teman sebaya ini dapat memberikan pengaruh yang baik terhadap siswa, dengan adanya tutor siswa dapat meningkatkan rasa percaya diri akan kemampuannya dalam belajar dan mengembangkan perilaku sosial ke sesama siswa yang lain. Peningkatan tersebut yang akan membuat siswa lebih termotivasi dalam hal belajar dan akan berdampak baik terhadap prestasinya.

Manfaat-manfaat ini yang akan berpengaruh terhadap self-regulated learning siswa, seperti yang telah diketahui bahwa seorang self-regulated learner mempunyai rasa percaya diri akan kemampuannya, bisa memotivasi diri sendiri untuk mencapai tujuan belajar yang diinginkan dan apabila mengalami kesulitan akan mencari bantuan orang lain. Jadi, berdasarkan uraian mengenai manfaat tutor teman sebaya dapat disimpulkan bahwa tutor teman sebaya dapat meningkatkan self-regulated learning siswa.

\subsection{Strategi Pembelajaran Peer Tutoring}

Secara umum strategi merupakan suatu garis-garis besar haluan untuk bertindak dalam usaha mencapai sasaran yang telah ditentukan. Terkait kegiatan belajar mengajar, strategi dapat diartikan sebagai pola-pola umum kegiatan guru anak didik dalam perwujudan kegiatan belajar mengajar guna mencapai kepada tujuan yang telah digariskan. Menurut Evelin Siregar, dkk (2010:77) strategi pembelajaran adalah cara sistematis yang dipilih dan digunakan seorang pembelajar untuk menyampaikan materi pembelajaran, sehingga memudahkan pembelajar mencapai tujuan pembelajaran tertentu.

Strategi pembelajaran peer tutoring merupakan suatu strategi pembelajaran di mana sekelompok siswa yang telah mampu menguasai bahan pelajaran, mengajari atau memberikan bantuan kepada siswa lainnya yang mengalami kesulitan dalam memahami bahan pelajaran yang dipelajarinya. Strategi pembelajaran peer tutoring ini pelaksanaannya yaitu dengan cara mengelompokkan siswa ke dalam kelompokkelompok kecil atau dapat disebut secara kooperatif, di mana sumber belajarnya bukan hanya bersumber dari guru melainkan juga dari teman sebaya yang pandai dan cepat dalam menguasai suatu materi tertentu. Pada strategi pembelajaran peer tutorting, siswa yang menjadi tutor hendaknya mempunyai tingkat kemampuan yang lebih tinggi dibandingkan siswa lainnya, sehingga di saat siswa yang mempunyai tingkat kemampuan yang lebih tinggi ini memberikan bimbingan, ia sudah dapat menguasai bahan yang akan disampaikan.

Depdiknas mengemukakan bahwa pembelajaran kooperatif merupakan suatu strategi pembelajaran yang diimplementasikan melalui kelompok kecil siswa yang saling bekerjasama dalam memaksimalkan kondisi belajar untuk mencapai tujuan belajar. Bern dan Erickson berpendapat bahwa kooperatif learning merupakan suatu strategi pembelajaran yang mengorganisir pembelajaran menggunakan kelompok belajar kecil dimana siswa saling bekerjasama untuk mencapai tujuan pembelajaran. Dalam hal ini siswa dikelompokkan ke dalam kelompok kelompok kecil secara kolaboratif dan anggotanya terdiri dari 2-5 orang, dengan struktur kelompoknya yang bersifat heterogen.

Strategi pembelajaran peer tutoring adalah suatu strategi pembelajaran yang bertujuan membantu siswa yang mengalami kesulitan dalam memahami materi pelajaran yang diajarkan guru dengan melibatkan siswa-siswa yang pandai atau berprestasi tinggi. Melalui tutor sebaya, siswa akan lebih mudah memahami suatu materi yang disampaikan guru dengan bantuan teman sebaya yang lebih mudah dipahami.

Peer tutoring merupakan sebuah strategi pembelajaran yang dapat mengembangkan ilmu pengetahuan siswa yang dibimbing, dapat membantu guru menilai siswa mana yang mampu memahami suatu materi dan siswa mana yang kurang/tidak mampu memahami materi dengan adanya bimbingan tutor kepada siswa yang diajarkan, serta dapat menjadikan hasil belajar siswa menjadi lebih baik. Dalam pelaksanaan peer tutoring, satu siswa yang pandai atau berprestasi tinggi memberikan pengajaran/bantuan akademik/pengajaran kepada siswa lainnya.

\section{Metodologi}

\subsection{Tempat, Waktu dan Subjek Penelitian}

Penelitian dilaksanakan di SMK Negeri 26 Jakarta yang berlokasi di Jalan Balai Pustaka Baru I, Rawamangun, Jakarta Timur. Penelitian dilaksanakan pada bulan April - Mei 2019 di kelas XI SIJA semester genap tahun ajaran 2018/2019. Penentuan waktu penelitian mengacu pada kalender akademik sekolah, karena pada penelitian memerlukan beberapa tahapan pelaksanaan yang membutuhkan proses belajar mengajar yang efektif di kelas. Subjek penelitian adalah siswa kelas XI SIJA 1 dan XI SIJA 2 SMKN 26 Jakarta. 


\subsection{Populasi dan Sampel Penelitian}

Populasi dalam penelitian ini adalah seluruh siswa kelas XI SMK Negeri 26 Jakarta yang berjumlah 432 yang terdiri dari 6 jurusan 12 kelas. Masing-masing kelas terdiri dari \pm 36 orang.

Sedangkan sampel yang digunakan dalam penelitian ini terdiri dari dua kelas yaitu XI SIJA 1 dan 2 SMK Negeri 26 Jakarta tahun pelajaran 2018/2019. Kelas SIJA 1 terdiri dari 33 orang dan kelas SIJA 2 terdiri dari 36 orang. Sehingga jumlah peserta didik yang menjadi sampel adalah 69 orang. Sampel diambil dengan cara probability sampling yaitu teknik pengambilan sampel yang memberikan peluang yang sama bagi setiap anggota populasi untuk dipilih menjadi sampel. Di mana populasi terjangkau secara cak sebanyak 69 siswa, kemudian ditetapkan satu kelas sebagai kelompok eksperimen dengan jumlah responden 33 siswa dan satu kelas lain sebagai kelompok kontrol dengan jumlah responden 36 siswa pula.

Dalam pengambilan sampel, peneliti menggunakan teknik acak sederhana (Simple Random Sampling). Hal ini dikarenakan kelas XI SIJA hanya terdapat 2 kelas yaitu kelas XI SIJA 1 dan XI SIJA 2 dan kedua kelas dianggap homogen. Oleh karena itu, kedua kelas tersebut dijadikan sampel. Kedua kelas tersebut dipilih secara random untuk mendapatkan kelas eksperimen dan kelas kontrol. Sehingga didapatkan Kelas XI SIJA I sebagai kelompok eksperimen dan Kelas XI SIJA II sebagai kelompok kelas kontrol.

\subsection{Definisi Operasional}

Variabel bebas dalam penelitian ini adalah strategi pembalajaran peer tutoring. Berdasarkan kerangka konseptual dan teori-teori yang sudah

dipaparkan sebelumnya variabel bebas mempengaruhi variabel lain (variabel terikat) yaitu strategi pembalajaran peer tutoring efektif dalam meningkatkan self-regulated learning siswa.

Sedangkan variabel terikat dalam penelitian ini adalah self-regulated learning. Setelah diberikan treatment peer tutoring, diharapkan self-regulated learning peserta didik meningkat. Maka self-regulated learning merupakan variabel terikat karena merupakan variabel yang dipengaruhi oleh variabel bebas (peer tutoring).

\subsection{Metode dan Rancangan Penelitian}

Penelitian ini menggunakan pendekatan penelitian kuantitatif dengan jenis penelitian eksperimen. Metode penelitian ini menggunakan
Quasi Experimental Design. Pemilihan metode penelitian ini karena sampel diambil secara acak (random sampling) kemudian digunakan satu kelas eksperimen untuk diberikan perlakuan (treatment) berupa strategi pembelajaran peer tutoring yaitu dibentuk kelompok dengan satu orang ahli yang menjadi tutor. Sedangkan kelas lainnya sebagai kelas kontrol tidak diberikan perlakuan pembelajaran peer tutoring melainkan diberikan pembelajaran biasa yaitu siswa menggali informasi sendiri, memecahkan sendiri masalah-masalahnya dan menyelesaikan sendiri tugas-tugas yang diberikan tanpa dibentuk kelompok.

Penggunakan strategi pembelajaran ini didasari oleh tujuan yang hendak dicapai pada penelitian yang menekankan seberapa efektif strategi pembelajaran peer tutoring dalam meningkatkan self-regulated learning siswa.

Desain penelitian ini adalah Nonequivalent Control Group Design. Desain penelitian ini menjelaskan ada dua kelompok penelitian yaitu Kelompok Eksperimen (KE) dan Kelompok Kontrol (KK). Kelompok ekesperimen diberikan treatment dan kelompok kontrol tidak diberikan treatment peer tutoring.

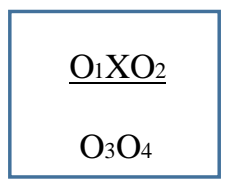

\section{Gambar 3.1 Nonequivalent Control Group Design 3.5. Prosedur Penelitian}

Dalam penelitian ekperimen terdapat prosedur atau tahapan yang perlu dilakukan. Prosedur yang dilakukan dalam penelitian ini terdiri dari 3 tahap yaitu pra ekperimen, ekperimen dan pasca eksperimen.

\subsection{Instrumen Penelitian}

Alur ukur terhadap self-regulated learning yang digunakan yaitu Motivated Strategies for Learning Questionnaire (Pintrich, Smith, Garcia dan McKeachie, 1991). Yang terdiri dari 9 indikator untuk mengukur strategi belajar skala self-regulated learning; rehearsal, elaboration, organisation, Critical thinking, Metacognitive self regulation, Time and study environment, Effort regulation, Help seeking, Peer learning.

\subsection{Teknik Pengumpulan Data}

Penelitian ini menggunakan pendekatan kuantitatif dengan jenis penelitian eksperimen. Teknik pengumpulan data yang digunakan dalam 
penelitian ini adalah wawancara, yaitu mewawancarai wali kelas XI SIJA. Peneliti juga menggunakan kuisioner untuk mengambil data pretest dan posttest. Selain itu selama Praktik Kegiatan Mengajar di SMKN 26 Jakarta peneliti melakukan observasi atau pengamatan langsung.

\subsection{Teknik Analisis Data}

Teknik yang dilakukan untuk menganalisis data yaitu:
a. Uji Normalitas
b. Uji Homogenitas
c. Uji Hipotestis

\section{Hasil dan Analisis}

\subsection{Deskripsi}

Penelitian ini terdiri dari kelas eksperimen (XI SIJA 1) yang berjumlah 33 orang dan kelas kontrol (XI SIJA 2) yang berjumlah 36 orang. Kemudian kelas eksperimen dibentuk menjadi 6 kelompok yang masing-masing terdiri dari satu tutor. Pembelajaran peer tutoring berlangsung 6 pertemuan dengan materi virtual private server.

\subsection{Pembahasan Hasil Penelitian. Berdasarkan Hasil Uji t-Test Pretest dan}

Posttest kelompok eksperimen dan kontrol memberikan hasil uji t hitung $=5,196$ dengan signifikansi $\mathrm{p}=0,000002$. Karena $\mathrm{p}(0,00002)<$ 0,05 maka ditemukan perbedaan yang signifikan antara kelompok eksperimen dan kelompok kontrol setelah diberikan treatment (posttest).

\section{a. Sebelum Diberikan Treatment}

Berdasarkan kategorisasi skala selfregulated learning skor siswa kelompok ekperimen berada pada kategori rendah sebesar 18\% dengan jumlah 6 siswa, pada kategori sedang sebesar $70 \%$ dengan jumlah 23 siswa dan pada kategori tinggi sebesar $12 \%$ dengan jumlah 4 siswa.

\section{b. Setelah Diberikan Treatment}

Berdasarkan kategorisasi skala selfregulated learning skor siswa kelompok ekperimen berada pada pada kategori tinggi sebesar 55\% dengan jumlah 18 siswa, kategori sedang sebesar $45 \%$ dengan jumlah 15 siswa dan tidak ada siswa yang berada pada kategori rendah. Dari data tersebut dapat disimpulkan bahwa self-regulated learning siswa kelas XI SIJA 1 sesudah diberikan treatment mengalami peningkatan.

\section{Kesimpulan dan Saran}

Berdasarkan hasil pengujian hipotses penelitian dan pembahasan dapat dimpulkan bahwa strategi pemberlajaran peer tutoring dapat meningkatkan self-regulated learning (SRL) siswa kelas XI SIJA SMKN 26 Jakarta. Hal ini dapat dilihat dati output perhitungan uji t skot posttest antara kelompok ekperimen dan kelompok kontrol yang menunjukan, hasil thitung $=5,196$ dengan signifikasi $\mathrm{p}=0,000002$. Karena p $(0,00002)<0,05$ pada signifikansi $5 \%$ sehingga dari hasil uji t tersebut dapat ditemukan perbedaan yang signifikan antara kelompok eksperimen dan kontrol setelah diberikan perlakukan (posttest). Selain itu, dapat diketahui dari hasil posttest melaui dari data mean, kelompok eksperimen mengalami peningkatan self-regulated learning (SRL) dari 103,727 (sebelum treatment) menjadi 125,512 (setelah diberikan treatment peer tutoring dari jumlah siswa sebanyak 33 orang. Sedangkan pada kelompok kontrol terdapat juga peningkatan nilai mean, namun hanya meningkat 103,25 menjadi 114,06 dari jumlah siswa sebanyak 36 orang. Berdasarkan hasil tersebut diketahui bahwa metode peer tutoring yang bertujuan untuk meningkatkan self-regulated learning (SRL) siswa mampu memberikan pengaruh peningkatan terhadap SRL siswa kelas XI SIJA 1 SMKN 26 Jakarta.

Berdasarkan kesimpulan tersebut di atas, selanjutnya dapat diberikan beberapa saran berikut ini; Untuk guru Bimbingan Konseling strategi peer tutoring ini bisa diterapkan dalam proses layanan bimbingan belajar atau pemberian materi bimbingan di kelas. Dengan self-regulated learning (SRL) yang tinggi, siswa diharapkan mampu meningkatkan prestasi belajar sesuai keinginan yang diharapkan. Bagi Lembaga Pendidikan (Sekolah). Diharapkan siswa dapat meningkatkan kemampuan self-regulated learning (SRL) yang dimiliki. Siswa mampu mengatur proses belajar yang meliputi perencanaan, pelaksaan dan evaluasi belajar, baik dalam aspek kognitif, efektif dan psikomotor untuk mencapai tujuan belajar. Hal ini mendorong siswa untuk lebih proaktif di kelas sesuai dengan kurikulum 2013 yang memiliki tujuan pembelajaran terpusat di siswa (student center). Bagi Subjek Kelas X jurusan SIJA SMK Negeri 26 Jakarta. Diharapkan siswa dapat meningkatkan kemampuan selfregulated learning (SRL) yang dimiliki. Sehingga siswa tahu bagaimana strategi yang paling efektif mengorganisasi cara belajar sehingga tujuan belajar sesuai apa yang diinginkan. Bagi Peneliti Selanjutnya. Untuk peneliti lebih lanjut disarankan dapat mempertimbangkan penggunaan metode peer tutoring untuk jenis penelitian lainnya. Atau selain itu, penelitian selanjutnya dapat mempertimbangkan strategi pembelajaran 
lainnya yang dapat meningkatkan SRL pada siswa selain strategi peer tutoring.

\section{Daftar Pustaka:}

Aina, Huru. (2017). PenerapanStrategi

Pembelajaran Peer-Tutor Untuk Meningkatkan Hasil Belajar Siswa Pada Mata Pelajaran Matematika Di Mas Babun Najah Banda Aceh. Skripsi, Tarbiyah dan Keguruan. Banda Aceh: Universitas Islam Negeri ArRaniry Darussalam-Banda Aceh

Anggraini, Catur Gesti. (2014). Efektivitas Metode Tutor Teman Sebaya Dalam Meningkatkan Self-Regulated Learning Siswa Kelas XI TKJ SMK Tarbiyatul Islam Kawunganten Kabupaten Cilacap. Skripsi, Prodi Bimbingan dan Konseling. Yogyakarta: Universitas Negeri Yogyakarta.

Artino, Anthony R., Jr. (2005). A Review of the Motivated Strategies for Learning Questionnaire (MSLQ). Arikunto, S. (2010). Prosedur Penelitian Suatu Pendekatan Praktek Edisi Revisi.Jakarta: Rineka Cipta.

Arrand, K. (2014). Peer Tutoring. Journal of Pedagogic Development. Volume 4 . Issue 1. Budiyono. (2004). Statistik Untuk Penelitian. Surakarta: UNS Press.

Dinata, Pri Ariadi Cahya. dkk. (2016). Self Regulated Learning Sebagai Strategi Membangun Kemandirian Peserta Didik Dalam Menjawab Tantangan Abad 21. Prosiding Seminar Nasional Pendidikan Sains: 139 - 146. Surakarta, 22 Oktober 2016: Universitas Sebelas Maret.

http://smkn26jkt.sch.id/web/sistem-informasiaplikasi-dan-jaringan/ (Diakses pada $11 \mathrm{Feb}$ 19 15:18 WIB)

https://smkbudimuliapakisaji.sch.id/sisteminformatika-jaringan-aplikasi// (Diakses pada 11 Feb 19 14:00 WIB)

Juliansyah. (2012). Metodologi Penelitian. Jakarta: Kencana

Jumanto dan Ema Butsi Prihatsari. (2018). Pengaruh Metode Tutor Sebaya Berbasis Video Youtube Terhadap Sikap Kemandirian Belajar Mahasiswa PGSD Unisri. Jurnal Profesi Pendidikan Dasar. Vol. 5, No. 1

Mardoh, Ryndi. (2015). Efektivitas Metode Peer Tutoring Dalam Meningkatkan SelfRegulated Learning (SRL) Siswa Kelas X SMK Negeri 1 Kalasan. Skripsi, Prodi Bimbingan Dan Konseling. Yogyakarta: Universitas Negeri Yogyakarta.
Montalvo, T.F \& Torres, G.C.M. (2004). SelfRegulated Learning Current and Future Directions. Electronic journal of research in educational psychology. 2(1). Hlm. 1-34. Musyrifah, Chilmiyyatul. (2016). Pengaruh Metode Tutor Sebaya (Peer Tutoring) Dalam Meningkatkan Self Regulation Siswa. Skripsi, Prodi Psikologi. Surabaya: Universitas Islam Negeri Sunan Ampel.

Naga, Dali Santun. (2002). Probabilitas dan Sekor Pada Hipotesis Statistika. Jakarta: UPT Penerbitan, Universitas Tarumanagara Nurfiani, Hana. (2015). Survei Kemampuan Self-Regulated Learning (SRL) Siswa Kelas X SMK Negeri 1 Kalasan. Skripsi, Prodi Bimbingan dan Konseling. Yogyakarta: Universitas Negeri Yogyakarta.

Nurhadiyanti, Ratih (2016) Hubungan Antara Self Regulated Learning Dengan Motivasi Belajar:(Studi Deskriptif Korelasional di SMK Sangkuriang 1 Cimahi Tahun Ajaran 2015/2016). Other thesis, Universitas Pendidikan Indonesia.

Pintrich, P. R., Smith, D. A. F., Garcia, T., \& McKeachie, W. J. (1991). A manual for the use of the Motivated Strategies for Learning Questionnaire (MSLQ). Ann Arbor: University of Michigan, National Center for Research to Improve Postsecondary Teaching and Learning.

Prof. Dr. Rully Indrawan, M.Si dan Prof. Dr. R. Poppy Yaniawati, M.Pd (2016). Metode Penelitian Kuantitatif, Kualitatif, dan Campuran untuk Manajemen, Pembangunan, dan Pendidikan. Bandung: Refika Aditama

Saifuddin Azwar. (2012). Penyusunan Skala Psikologi. Yogyakarta: Pustaka Pelajar.

Schunk, D. H. (1989). Social Cognitive Theory and Self-Regulated Learning. Springer Series in Cognitive Development, 83-110. Sugiyono. (2017). Metode penelitian kuantiatif kualitataif dan $R \& D$. Bandung: Alfabeta.

Sumadi Suryabrata. (2012). Metodologi Penelitian. Jakarta : PT Raja Grafindo Persada

Sumarni, iis. (2016). Perbandingan Model Pembelajaran Project Based Learning (PJBL) Dengan Model Pembelajaran Kooperatif Tipe Student Teams Achievment Division (STAD) Terhadap Hasil Belajar Siswa Pada Mata Pelajaran Perakitan Komputer Kelas X Teknik Komputer Jaringan Smk Negeri 26 Jakarta. Skripsi, Prodi Pendidikan Teknik Informatika dan Komputer. Jakarta: Universitas Negeri Jakarta. 
Suyono dan Hariyanto. (2016). Belajar dan Pembelajaran. Bandung: Rosda.

Wangid, Nur Muhammad. (2017). Efektivitas Tutor Sebaya Dan Pekerjaan Rumah Dalam Meningkatkan Self- Regulated Learning Siswa. Jurnal Kependidikan. Vol. 1 No. 2. Yulianti, Putri., Sano, Safrizal., \& Ifdil. (2016). Self Regulated Learning Siswa Dilihat Dari Hasil Belajar. Indonesian Institute for Counseling, Education and Therapy (IICET).

Zimmerman, B.J. (1989). A Social Cognitive View of Self Regulated Academic Learning. Journal of Educational Psychology, 3, 329-339.

Zimmerman, B.J. (1990). Self-Regulated Learning and Academic Achievement : an Overview. Journal of Educational Pshychologist. 25(1). Hlm. 3 - 17. Lawrence Erlbaum associates.

Zumbrunn, S., Tadlock, J., \& Roberts, D.E. (2011). Encouring Self-Regulated Learning in The Classrom : A Review of The Literature. Metropolitan Educational Research Consortium (MERC). Virginia Common wealth University 